\title{
Invited review: Anaerobic fermentation of dairy food wastewater
}

\author{
A. N. Hassan* and B. K. Nelson ${ }^{1}$ \\ *Dairy Science Department, South Dakota State University, Brookings 57007 \\ †Daisy Brand LLC, Garland, TX 75041
}

\section{ABSTRACT}

Dairy food wastewater disposal represents a major environmental problem. This review discusses microorganisms associated with anaerobic digestion of dairy food wastewater, biochemistry of the process, factors affecting anaerobic digestion, and efforts to develop defined cultures. Anaerobic digestion of dairy food wastewater offers many advantages over other treatments in that a high level of waste stabilization is achieved with much lower levels of sludge. In addition, the process produces readily usable methane with low nutrient requirements and no oxygen. Anaerobic digestion is a series of complex reactions that broadly involve 2 groups of anaerobic or facultative anaerobic microorganisms: acidogens and methanogens. The first group of microorganisms breaks down organic compounds into $\mathrm{CO}_{2}$ and volatile fatty acids. Some of these organisms are acetogenic, which convert long-chain fatty acids to acetate, $\mathrm{CO}_{2}$, and hydrogen. Methanogens convert the acidogens' products to methane. The imbalance among the different microbial groups can lead not only to less methane production, but also to process failure. This is due to accumulation of intermediate compounds, such as volatile fatty acids, that inhibit methanogens. The criteria used for evaluation of the anaerobic digestion include levels of hydrogen and volatile fatty acids, methane:carbon ratio, and the gas production rate. A steady state is achieved in an anaerobic digester when the $\mathrm{pH}$, chemical oxygen demand of the effluent, the suspended solids of the effluent, and the daily gas production remain constant. Factors affecting efficiency and stability of the process are types of microorganisms, feed $\mathrm{C}: \mathrm{N}$ ratio, hydraulic retention time, reactor design, temperature, $\mathrm{pH}$ control, hydrogen pressure, and additives such as manure and surfactants. As anaerobic digesters become increasingly used in dairy plants, more research should be directed toward selecting the best cultures that maximize methane production from dairy food waste.

Received May 15, 2012.

Accepted July 21, 2012.

${ }^{1}$ Corresponding author: bnelson@daisybrand.com
Key words: dairy food waste, anaerobic digestion, methane, whey

\section{INTRODUCTION}

The amount of organic material in dairy industry wastewater varies considerably (Gough et al., 1987). Levels of fat, lactose, and protein are in the range of 35 to 500,250 to 930 , and 210 to $560 \mathrm{mg} / \mathrm{L}$, respectively (Lalman et al., 2004). Wastewater from the dairy food manufacturing sector is high in chemical oxygen demand (COD), biological oxygen demand (BOD), and volatile solids (Demirel et al., 2005). This high COD is mainly due to lactose, which is the major solid constituent in wastewater from dairy foods. The demand for whey protein concentrate and isolate products has reduced dairy food waste from manufacturing facilities; however, lactose is not as broadly used in food products. Therefore, lactose, the most abundant milk solid, generally remains a waste product. Hobman (1984) recognized this issue and described anaerobic digestion to produce methane as a potentially profitable use of lactose in deproteinized milk serum. He listed 11 laboratory or pilot-scale studies that used cheese whey or deproteinized milk serum for anaerobic digestion. Although the amount of undervalued lactose is increasing, the conversion of lactose to methane by commercial anaerobic process is uncommon.

Due to the increased volume of dairy processing byproducts (whey or permeate), increased size of dairy plants, and strict legislative requirements, finding a novel cost-effective disposal or utilization method for waste has been an important issue for the dairy industry (Mawson, 1994). The discharge of dairy waste, such as cheese whey, onto land can have a negative effect on the chemical and physical structure of soil, reduce crop yield, and pollute groundwater (Ben-Hassan and Ghaly, 1994). Air quality can also be affected, as reported by Bullock et al. (1995) who found that high levels of CO were released when whey was land applied to alfalfa on silt loam calcareous soil.

Aerobic and anaerobic treatment could be viable options for dairy plants because of the high investment costs of whey processing and environmental issues as- 
sociated with land application. Aerobic digestion has been used to treat municipal sewage. In aerobic fermentation, microorganisms grow rapidly and most of the energy is used for bacterial cell growth, not biogas production (Gough et al., 1987). Only about half of the degradable organic compounds in wastewater can be stabilized by aerobic digestion, whereas up to $90 \%$ can be degraded in anaerobic digestion (McCarty, 1964; Demirel et al., 2005). In addition, little or no dilution of high strength waste is required in the anaerobic process. Lower nutrients and no oxygen are required for anaerobic digestion. If methane is used to produce electricity, anaerobic treatment of municipal waste results in a net positive energy balance. The net negative energy balance of aerobic digestion is due, in large part, to the power consumption of the aeration system (Speece, 2008). Sludge production, energy input, and air pollution by odorous materials are drastically reduced with anaerobic digestion (Ryhiner et al., 1993). Anaerobic digestion requires complex reactions, which involve various groups of undefined anaerobic microorganisms including methane-producing archaea (Demirel et al., 2005). The lower cost of anaerobic treatment equipment makes this an attractive alternative for the dairy industry. However, the principles of operation are more complex. This review addresses various topics related to anaerobic digestion of dairy food wastewater, including microorganisms, biochemistry, factors effecting fermentation, and development of effective defined starter cultures.

\section{MICROORGANISMS ASSOCIATED WITH METHANE PRODUCTION}

The microbial composition of anaerobic digestion systems is not defined. Commercial starters for anaerobic digestion of dairy waste are not available. Instead, sludge from waste treatment systems is usually used to start new digesters (Chartrain et al., 1987). Although microorganisms involved in anaerobic digestion are not fully identified, at least 4 groups of microorganisms are involved in this process (Chartrain et al., 1987; Lee et al., 2008). The first group is the hydrolytic bacteria that degrade complex OM (protein, carbohydrates, and fat) into simpler compounds, such as organic acids, alcohols, $\mathrm{CO}_{2}$, and hydrogen. The second group is the hydrogenproducing acetogenic bacteria that use organic acids and alcohols to produce acetate and hydrogen. Low $\mathrm{H}_{2}$ partial pressure is essential for acetogenic reactions to be thermodynamically favorable (Stams et al., 1998). Different metabolic pathways produce various levels of hydrogen from a particular substrate. The conversion of $1 \mathrm{~mol}$ of glucose into butyrate is accompanied by production of only $2 \mathrm{~mol}$ of $\mathrm{H}_{2}$. Whole glucose conver- sion into propionic acid and ethanol lead to negative and zero yield of hydrogen, respectively. Glucose can be directly converted to acetic acid with no hydrogen production. However, up to $4 \mathrm{~mol}$ of hydrogen could also be produced from glucose in acetic acid fermentation (Venetsaneas et al., 2009). The third group is homoacetogenic bacteria that form only acetate from hydrogen and $\mathrm{CO}_{2}$, organic acids, alcohols, and carbohydrates. Fatty acids longer than 2 carbon atoms, alcohols with greater than 1 carbon atom, and branched-chain and aromatic FA cannot be used directly in methanogenesis. Such large molecules need to be oxidized to acetate and $\mathrm{H}_{2}$ by obligated proton-reducing bacteria in a syntrophic relationship with methanogenic archaea. The fourth group comprises methanogens that form methane from acetate, $\mathrm{CO}_{2}$, and hydrogen. Hydrolytic, acetogenic, and methanogenic microorganisms play an equally important role in methane production.

Optimal methane production is only achieved with interactions of microorganisms (Chartrain et al., 1987). Imbalance among the different microbial groups can lead not only to less methane production but also to process failure (Lee et al., 2008). This is due to accumulation of intermediate compounds that inhibit methanogens (Lee et al., 2008). In a fixed-film acid whey anaerobic digester, $55 \%$ of the isolates were fermentative, $5 \%$ acetogenic, and $40 \%$ methanogenic (Zellner and Winter, 1987). In another anaerobic digester of sweet whey, the counts of lactose-hydrolyzing bacteria, hydrogen-producing acetogens, and methanogens were $10^{10}, 10^{8}$ to $10^{10}$, and $10^{6}$ to $10^{9}$, respectively (Chartrain and Zeikus, 1986a). Biodegradation of OM in dairy wastewater depends on the activity of all microbial groups involved.

Major differences are found in the growth rate of various groups of microorganisms involved in anaerobic fermentation. For example, the minimum doubling time at $35^{\circ} \mathrm{C}$ is $30 \mathrm{~min}$ for sugar-fermenting acid-forming bacteria, $6 \mathrm{~h}$ for methanogens growing on hydrogen or formate, $1.4 \mathrm{~d}$ for acetogenic bacteria fermenting butyrate, $2.5 \mathrm{~d}$ for acetogenic bacteria fermenting propionate, and $2.6 \mathrm{~d}$ for methanogenic using acetate (Mosey and Fernandes, 1989). The 2 main steps (acidogenesis and methanogenesis) are normally not in balance $(2$ different rates) even at low digester feed rates (Yan et al., 1993). If they remain in balance, the intermediate products such as VFA would not be detectable (Yan et al., 1993).

Molecular techniques have been used to investigate bacterial community shifts and relate them to biochemical changes in the anaerobic fermentation. Methane production in a continuously stirred tank reactor fed whey permeate started at $4.7 \mathrm{~d}$ of fermentation when the microbial population shifted toward Archaea, with 
a decline in acidogens (Lee et al., 2008). Methane production stopped at $18.9 \mathrm{~d}$ when acetate was completely consumed and started again at $29.9 \mathrm{~d}$ when acetate was produced from propionate (Lee et al., 2008). Bacterial growth continued during the methanogenic stage (Lee et al., 2008). Hydraulic retention time (HRT) has a significant effect on counts and diversity of microbial populations. The lactose-hydrolyzing population was not affected by HRT ranging from 25 to $100 \mathrm{~h}$ (Chartrain et al., 1987). However, the acetate-degrading organisms decreased to insignificant levels at HRT below $12 \mathrm{~h}$ (Chartrain et al., 1987). The fermentation temperature and $\mathrm{pH}$ are among factors affecting species composition and dominance of bacteria groups in anaerobic fermentations (ten Brummeler et al., 1985; Tzeng, 1985). The high affinity of microorganisms to adhere to surfaces prevents their washout, which can affect the microbial composition and the fermentation process in bioreactors using immobilized cell technology (Yang and Guo, 1990).

Common fermentative bacteria are Lactobacillus, Eubacterium, Clostridium, Escherichia coli, Fusobacterium, Bacteroides, Leuconostoc, and Klebsiella. Examples of acetogens are Acetobacterium, Clostridium, and Desulfovibrio.

According to Boone and Castenholz (2001), methaneproducing organisms are classified under domain Archaea, phylum AII, Euryarchaeota. Archaea is a group of prokaryotes that differ from bacteria. Some Archaea can survive extremely harsh conditions, such as hypersalinity or high temperatures (up to $110^{\circ} \mathrm{C}$ ). Their cell wall lacks peptidoglycan-containing muramic acid and the nucleotide sequence of $5 \mathrm{~S}, 16 \mathrm{~S}$, and $23 \mathrm{~S}$ rRNA are different from those in bacteria. Gram stains of Archaea vary due to major differences in the composition of the cell envelope within the same subgroup. Methanogens are rod-shaped, lanced-shaped, or coccoids. They reduce $\mathrm{CO}_{2}$ or sometimes methyl compounds and produce methane as the major product, whereas hydrogen, formate, or secondary alcohols serve as the electron donors. There are 5 orders of methanogens: Methanobacteriales, Methanococcales, Methanomicrobiales, Methanosarcinales, and Methanopyrales and 9 families: Methanobacteriaceae, Methanothermaceae, Methanococcaceae, Methanocaldococcaceae, Methanomicrobiaceae, Methanocorpusculaceae, Methanospirillaceae, Methanosarcinaceae, and Methanosaetaceae. Characteristics of the Archaea families are shown in Tables 1 and 2. Organisms with optimal growth temperatures higher than $60^{\circ} \mathrm{C}$ were not included in the tables due to their impracticality. As temperatures of common dairy waste products, such as whey and permeate, are below $60^{\circ} \mathrm{C}$, higher anaerobic fermentation temperatures would require more energy for heating.
Fermentations at such high temperatures would be costly with special equipment design considerations.

\section{BIOCHEMISTRY OF ANAEROBIC DIGESTION OF DAIRY FOOD WASTE}

\section{Anaerobic Digestion of Fat}

Milk fat represents 4 to $22 \%$ of the DM of wastewater from dairy plants (Sage et al., 2008). It consists mainly of a mixture of triglycerides (more than 97\%). In addition to triglycerides, milk lipids contain some additional compounds such as mono- and diglycerides, FFA, phospholipids, and vitamins (E, D, A, and $\mathrm{K}$ ). About $60 \%$ of FA in milk are saturated, with oleic and linoleic representing most of the unsaturated FA. Oleate and palmitate are the most common FA in dairy food wastewater (Hanaki et al., 1981; Lalman et al., 2004). The metabolism of milk fat during anaerobic digestion is shown in Figure 1. Milk fat is first hydrolyzed by lipases from acidogenic bacteria, such as clostridia and micrococci (Miyamoto, 1997), to glycerol and long-chain FFA. Inside the bacterial cell, acidogenesis converts glycerol to acetate. Acetyl-CoA and a FA that has been shortened by 2 carbons are produced by $\beta$-oxidation of saturated FFA. This cycle repeats until all FFA have been completely reduced to acetyl-CoA or acetyl-CoA and $1 \mathrm{~mol}$ of propionyl-CoA/mol of FA (in FA with odd numbers of carbon atoms). Propionate is then decarboxylated to acetate, $\mathrm{CO}_{2}$ and $\mathrm{H}_{2}$. Therefore, the final products of $\beta$-oxidation of FA are acetate, $\mathrm{H}_{2}$, and $\mathrm{CO}_{2}$. Examples of bacteria responsible for $\beta$-oxidation are Syntrophomonas wolfei and Sytrophobacter wolinii (Miyamoto, 1997).

The yield of methane produced from lipids is much higher than from carbohydrates or proteins. However, lipids can physically and chemically interfere with anaerobic digestion (Kim et al., 2004; Cirne et al., 2007; Sage et al., 2008). Due to high hydrophobicity, milk fat adsorbs into the biomass, interferes with bioassimilability, and limits access to other substrates. Adsorption of fat causes flotation of the microbial mass and washout, especially with high-rate anaerobic reactor systems, such as the upflow anaerobic sludge blanket or the expanded granular sludge bed (Cammarota et al., 2001). Cirne et al. (2007) and Vidal et al. (2000) reported that fat levels up to 18 and 16\% (wt/wt, COD basis), respectively, did not affect the methane production rate.

Free FA resulting from fat hydrolysis can inhibit hydrogen-producing bacteria responsible for $\beta$-oxidation, acetoclastic bacteria (convert acetate to methane), and hydrogenotrophic methanogens (produce methane from hydrogen; Hanaki et al., 1981; Kim et al., 2004). This inhibition leads to a lag phase of several days, which 
Table 1. Characteristics ${ }^{1}$ of the families Methanobacteriaceae, Methanomicrobiaceae, and Methanocorpusculaceae

\begin{tabular}{|c|c|c|c|c|c|c|c|c|}
\hline Genus & $\begin{array}{c}\text { Cell } \\
\text { width } \\
(\mu \mathrm{m})\end{array}$ & $\begin{array}{c}\text { Optimal } \\
\text { temperature } \\
\left({ }^{\circ} \mathrm{C}\right)\end{array}$ & \multicolumn{6}{|c|}{ Substrate for methane production ${ }^{2}$} \\
\hline \multicolumn{9}{|c|}{ Family Methanobacteriaceae } \\
\hline Methanobrevibacter & $0.5-0.7$ & $37-40$ & $\mathrm{x}$ & & $\mathrm{x}$ & & & \\
\hline Methanosphaera & 1.0 & 37 & $\mathrm{x}$ & & & $\mathrm{x}$ & & \\
\hline Methanothermobacter & $0.3-0.5$ & $55-65$ & $\mathrm{x}$ & & $\mathrm{x}$ & & & \\
\hline Methanoculleus ${ }^{4}$ & $0.5-2.0$ & $20-45$ & $\mathrm{x}$ & $\mathrm{x}$ & $\mathrm{x}$ & & & \\
\hline Methanofollis ${ }^{5}$ & $1.5-3.0$ & $37-40$ & $\mathrm{x}$ & $\mathrm{x}$ & $\mathrm{x}$ & & & \\
\hline Methanogenium ${ }^{5}$ & $0.5-2.6$ & $15-57$ & $\mathrm{x}$ & $\mathrm{x}$ & $\mathrm{x}$ & & & \\
\hline Methanolacinia ${ }^{4}$ & 0.6 & 40 & $\mathrm{x}$ & $\mathrm{x}$ & & & & \\
\hline Methanoplanus & $1-2$ & $32-40$ & $\mathrm{x}$ & & $\mathrm{x}$ & & $\mathrm{x}$ & \\
\hline \multicolumn{9}{|c|}{ Family Methanocorpusculaceae } \\
\hline Methanocorpusculum & $<2.0$ & $30-40$ & $\mathrm{x}$ & $\mathrm{x}$ & $\mathrm{x}$ & & & \\
\hline
\end{tabular}

${ }^{1}$ Adapted from Boone and Castenholz (2001).

${ }^{2}$ One, some, or all species.

${ }^{3} \mathrm{Sec} \mathrm{OH}=$ secondary alcohols.

${ }^{4}$ Salt enhances growth.

${ }^{5}$ Salt may or may not be required for growth, depending on species.

${ }^{6}$ Family is not assigned but closely related to Methanocorpusculaceae.

reduces the rate of methane production (Lalman and Bagley, 2000; Sage et al., 2008). Inhibition of anaerobic bacteria by FA depends on concentration, chain length, and the level of unsaturation (Lalman and Bagley, 2000; Kim et al., 2004). Sage et al. (2008) showed that the lag phase was mainly due to unsaturated FFA. Perle et al. (1995) reported that milk fat produced similar results as oleate plus glycerol in reducing biogas production and ATP content. This indicates a biochemical inhibition of methane production by unsaturated FA. Data by Pereira et al. (2005) supported the hypothesis that the inhibitory effect of unsaturated FA on methane production was primarily due to their adsorption into the biomass, which prevented substrate and product transfer. The inhibited methanogens recovered their activity after the long-chain FA associated with the biomass were converted to methane (Cavaleiro et al., 2008). Pereira et al. (2004) indicated that concentrations of long-chain FA below $1,000 \mathrm{mg} / \mathrm{g}$ of volatile solids would not inhibit methane production. Conversion of SFA to methane occurs at a lower rate than unsaturated FA due to their lower solubility (Sage et

Table 2. Characteristics ${ }^{1}$ of the families Methanospirillaceae, Methanosarcinaceae, and Methanosaetaceae

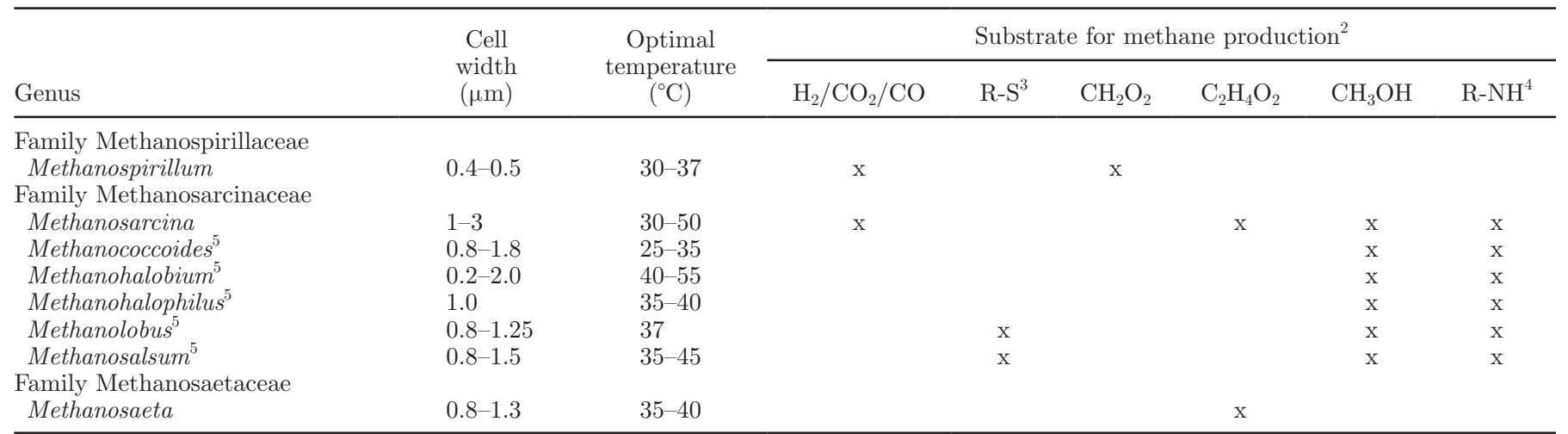

\footnotetext{
${ }^{1}$ Adapted from Boone and Castenholz (2001).

${ }^{2}$ One, some, or all species.

${ }^{3} \mathrm{R}-\mathrm{S}=$ methyl sulfide or dimethyl sulfide.

${ }^{4} \mathrm{R}-\mathrm{NH}=$ methyl-, dimethyl-, or trimethylamine.

${ }^{5}$ Salt enhances growth.
} 


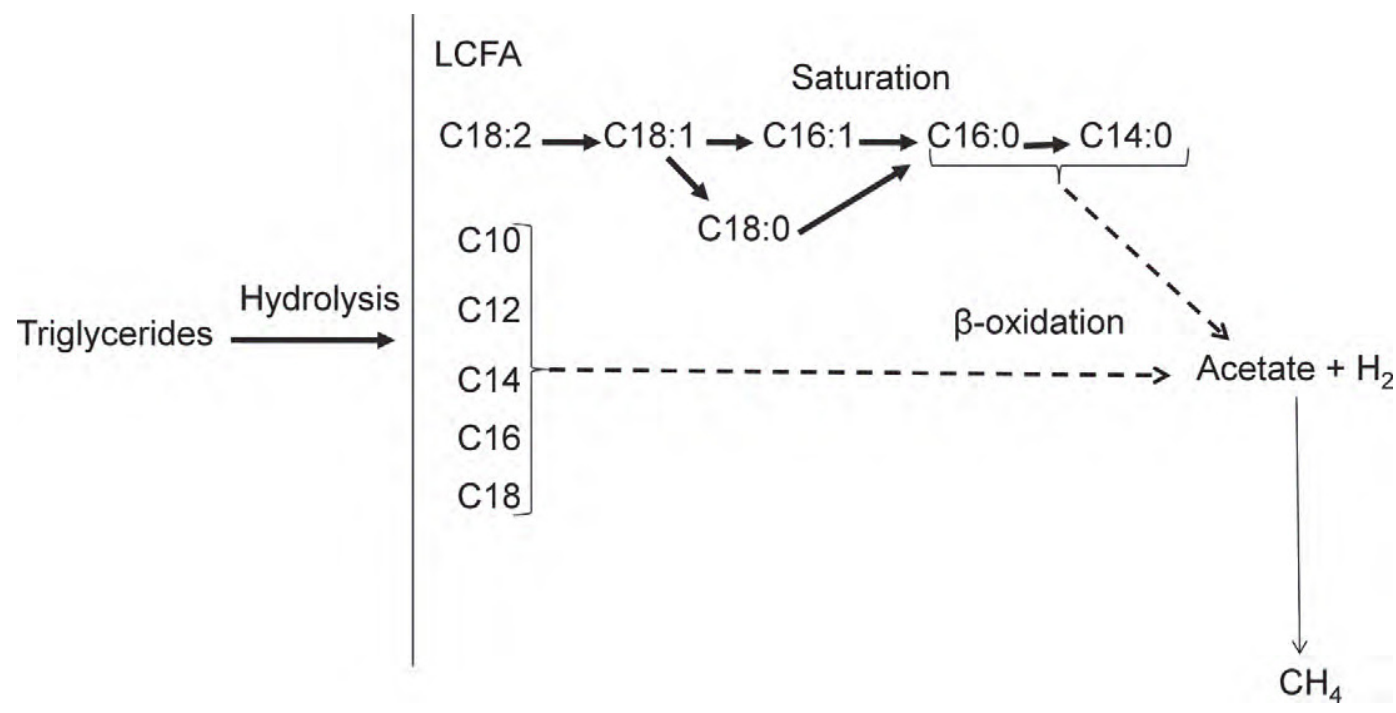

Figure 1. Anaerobic digestion of milk fat (adapted from Sage et al., 2008, J. Dairy Sci. 91:4062-4074, with permission of the publisher). $\mathrm{LCFA}=$ long-chain FA.

al., 2008). Prehydrolysis of fat by lipase results in accumulation of unsaturated FFA, which increases the lag phase before methane production (Cirne et al., 2007; Sage et al., 2008). However, Rosa et al. (2009) found that prehydrolysis of milk fat by fungal lipase improved the COD removal efficiency. They related this pretreatment effect to changes in the predominant bacteria and Archaea. Cirne et al. (2006), using the bioaugmenting lipolytic strain Clostridium lundense in lipid-rich waste, demonstrated increased methane yield and production rate due to increased bioavailability of the substrate. In addition, the lipolytic strain enhanced $\beta$-oxidation, which released hydrogen, thereby stimulating hydrogenotrophic methanogens.

\section{Anaerobic Digestion of Lactose}

Lactose is converted to several different intermediates before final conversion to methane (Figure 2). Most anaerobic bacteria use the Emden Meyerhof-Parnas pathway for lactose metabolism. This pathway produces pyruvate and reduced NAD (NADH), which are transformed into lactate, acetate, ethanol, and other metabolites. Chartrain and Zeikus (1986a) found that the major intermediate metabolites of anaerobic lactose digestion are acetate, lactate, ethanol, and formate, with lower levels of propionate and valerate. Acetate accounted for more than $70 \%$ of the intermediate metabolites produced from lactose (Chartrain and Zeikus, 1986a). The major end products included methane, $\mathrm{CO}_{2}$, and cellular carbon at the ratio of 1:0.94:0.25 (Chartrain and Zeikus, 1986a). In addition, the minor end products included acetate, lactate, propionate, butyrate, ethanol, and $\mathrm{H}_{2}$ (Chartrain and Zeikus, 1986a).
Lactose-digesting bacteria isolated from whey anaerobic digesters include Leuconostoc mesenteroides, Klebsiella oxytoca, and Clostridium butyricum (Chartrain and Zeikus, 1986b). Leuconostoc ferments lactose

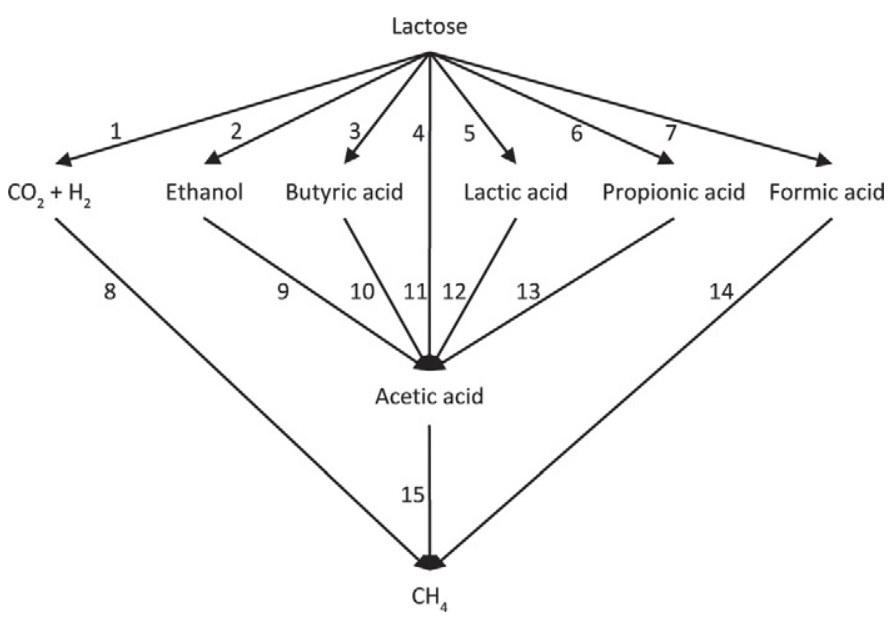

Figure 2. Possible pathways for anaerobic conversion of lactose to methane. Examples of microorganisms associated with the above reactions are as follows: reaction 1: Leuconostoc mesenteroides, Escherichia coli; reaction 2: L. mesenteroides, E. coli; reaction 3: Clostridium butyricum; reaction 4: L. mesenteroides, C. butyricum, Eubacterium spp.; reaction 5: Streptococcus thermophilus, Lactococcus lactis, Lactobacillus delbrueckii ssp. bulgaricus; reaction 6: Clostridium propionicum; reaction 7: Strep. thermophilus, Actinobacillus succinogenes, Mannheimia succiniciproducens, E. coli; reaction 8: Methanomicrobium, Methanobrevibacter, Methanocalculus; reaction 9: Desulfovibrio spp., Clostridium tyrobutyricum; reaction 10: Syntrophomonas wolfei; reaction 11: Clostridium formicoaceticum, Acetobacterium woodii, Desulfovibrio spp.; reaction 12: Methanosarcina, Methanosaeta; reaction 13: Syntrophobacter wolinii; reaction 14: Methanomicrobium, Methanoculleus, Methanofollis; reaction 15: Methanosarcina, Methanosaeta. 
to glucose, acetate, and ethanol. Clostridium ferments lactose to butyrate, acetate, ethanol, hydrogen, and $\mathrm{CO}_{2}$. Klebsiella ferments lactose to acetate, ethanol, lactate, hydrogen, and acetoin (Chartrain and Zeikus, 1986b). Desulfovibrio vulgaris is a common hydrogenproducing acetogenic bacterium that utilizes lactate, ethanol, and hydrogen (Chartrain et al., 1987). In the presence of sulfate, it ferments lactate into acetate, $\mathrm{H}_{2} \mathrm{~S}$, and small amounts of ethanol with trace amounts of hydrogen (Chartrain et al., 1987). Desulfovibrio vulgaris also produces acetate, $\mathrm{H}_{2} \mathrm{~S}$, and trace amounts of hydrogen from ethanol. Clostridium propionicum is an acetogen that ferments lactate into acetate, propionate, hydrogen, and $\mathrm{CO}_{2}$. The accumulation of the intermediate products from lactose fermentation leads to inhibition of microorganisms with lower methane production (Aguilar et al., 1995). During startup, if $\mathrm{pH}$ values are below 4.5, fermentation of lactose produces $\mathrm{CO}_{2}$ or hydrogen. The presence of $\mathrm{CO}_{2}$ in the early stages of fermentation reduces VFA available for methane production. Generally, about $70 \%$ of methane is produced from acetic acid and 30\% from $\mathrm{CO}_{2}$ and hydrogen (McCarty and Smith, 1986).

\section{Anaerobic Degradation of Protein}

Protein hydrolysis, which depends mainly on acclimation of the microorganisms, is slower than that of carbohydrates (Yu and Fang, 2001). Acclimation of microorganisms in sludge to casein substantially increased proteolysis (Perle et al., 1995). By comparing sweet whey feed material with lactose, Kisaalita et al. (1990) demonstrated that the presence of whey proteins, although slowing fermentation, produced similar byproducts in the acidogenic stage of treatment. Steps involved in the conversion of proteins to methane are shown in Figure 3. Proteins are hydrolyzed by extracellular proteases into peptides. Peptides are broken down by peptidases to amino acids. Amino acids are degraded by different pathways to various end products, including organic acids, ammonia, $\mathrm{CO}_{2}$, and small amounts of hydrogen and sulfur-containing compounds. In the oxidation of an amino acid, the electron acceptor could be another amino acid (Stickland reaction) or hydrogen-consuming bacteria (methanogens; Ramsay and Pullammanappallil, 2001). Single amino acids can be fermented in the presence of hydrogen-utilizing bacteria (such as methanogens). Nagase and Matsuo (1982) found that the Stickland reaction was the most common amino acid oxidation reaction in anaerobic digestion; however, Ramsay and Pullammanappallil (2001) reported that $60 \%$ of amino acid (from casein) degradation involved uncoupled amino acids (amino acids that do not serve as electron acceptors).

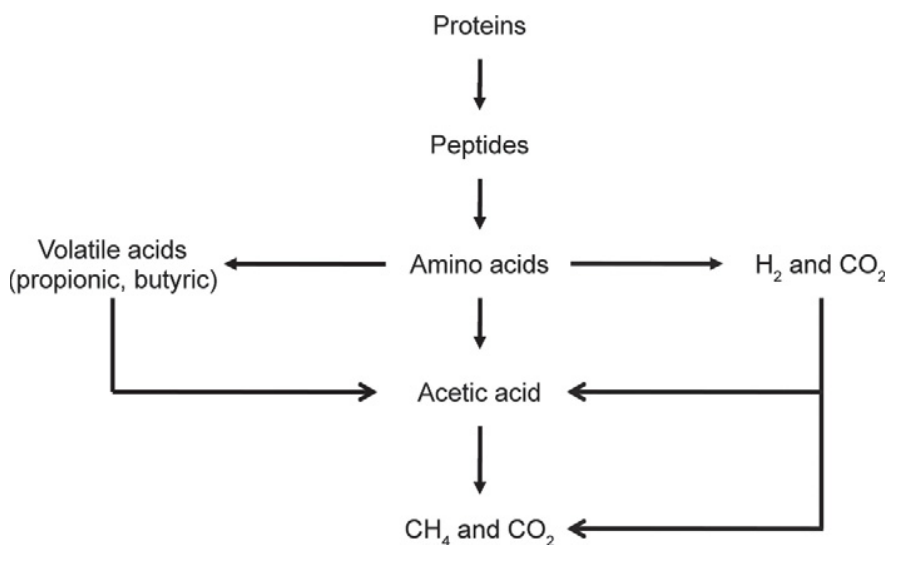

Figure 3. Anaerobic degradation of milk proteins.

The predominant proteolytic bacteria in anaerobic digesters are gram positive (mainly Clostridium spp.; McInerney, 1988). Other proteolytic bacteria include Bacteroides, Butyrivibrio, Fusobacterium, Selenomonas (Miyamoto, 1997), and lactic acid bacteria. In addition to Clostridium spp., other amino acid-degrading microorganisms include Peptostreptococcus, Campylobacter spp., Acidaminococcus fermentans, Acidaminobacter hydrogenoformans, Megasphaera elsdenii, Eubacterium acidaminophilum, and some sulfate-reducing bacteria (Zindel et al., 1988; Ramsay and Pullammanappallil, 2001). Although concentrations up to $200 \mathrm{mg} / \mathrm{L}$ of ammonia may stimulate methanogenic bacteria, higher levels of its unionized form may be toxic (Anderson et al., 1982; Parkin et al., 1983; Koster and Lettinga, 1988).

\section{FACTORS AFFECTING METHANE PRODUCTION FROM DAIRY FOOD WASTE}

\section{Digester Design}

Anaerobic digestion of $\mathrm{OM}$ is a slow process requiring long HRT. Economically, short HRT would be desirable (Mawson, 1994). Various anaerobic digestion systems are summarized in Table 3. Available data from largescale operations are sparse. Generally, loading rates of up to $10 \mathrm{~kg}$ of $\mathrm{COD} / \mathrm{m}^{3}$ per day with more than $75 \%$ reduction can be achieved with gas production up to $38 \mathrm{~m}^{3}$ containing approximately $60 \%$ methane (Clark, 1988; Kemp and Quickenden, 1988; Mawson, 1994). One of the simplest designs is a continuously stirred tank reactor, but one challenge is the loss of cells in the effluent. Cell retention can be achieved by internal or external recycling of the biomass or cell immobilization (Mawson, 1994). Examples of high-rate digestion systems are downflow-upflow hybrid reactors (DUHR), anaerobic moving-bed biofilm reactors (AMBBR), 
upflow anaerobic sludge blanket reactors (UASBR), packed-bed immobilized cell bioreactors, anaerobic attached- (fixed-) film expanded beds, downflow stationary fixed-film reactors, upflow fixed films, upflow fixed-film loop reactors, and anaerobic rotating biological contact reactors (ARBCR).

Upflow Anaerobic Sludge Blanket Reactor. A UASBR is the most common and suitable configuration for food industry wastewater treatment due to its ability to treat large volumes in a relatively short period of time (Demirel et al., 2005). In this design, wastewater flows upwards through a blanket of granular sludge. Cells are retained within the reactor because of a section of dense flocculated sludge that settles in the tank. Yan et al. (1993), using a UASBR without pH control, achieved higher $\mathrm{pH}$, lower VFA, and higher COD reduction in the upper methanogenic than the lower acidogenic section of the reactor from diluted whey adjusted to $\mathrm{pH}$ 7.0. Increasing the substrate loading rate expands the acidogenic reaction into the upper portion and causes process failure. Yan et al. (1993) observed optimal influent concentrations for a USABR between 5 and $28 \mathrm{~g}$ of COD/L with 5-d HRT.

The anaerobic baffled reactor is a modification of the UASBR, which operates without extensive sludge granulation because of compartments between baffles. Skiadas and Lyberatos (1998) developed the periodic anaerobic baffled reactor, which allowed flexibility of operation to accommodate loading conditions. A periodic anaerobic baffled reactor could be operated as an anaerobic baffled reactor or UASBR at high or low HRT, respectively.

Downflow-Upflow Hybrid Reactor. The high biodegradability of whey (about $70 \mathrm{~g}$ of COD/L), the low alkalinity, and the difficulty to obtain granulation makes UASBR difficult to use. The DUHR was specifically developed for cheese whey (Malaspina et al., 1996). This hybrid system comprised an acidification chamber that was a downflow stationary fixed-film, channeled polyurethane filter reactor that opened at the bottom to an upflow chamber with a similar filter in the upper $40 \%$ of the chamber. The volume ratio of the acidification and methanogenic chambers was 1:5. The design of this section reduced the passage of acidogens to the upflow compartment and made the use of more concentrated whey possible. Recycling from the top of the second section provided alkalinity and diluted the influent. In this design, phases were separated and the influent was introduced at the top of the downflow reactor where mixing and bacterial activity were high. This design reduced the risk of $\mathrm{pH}$ drop if the recycle pump failed. The DHUR allowed high stability at high organic loading rate with no $\mathrm{pH}$ control. It maintained
$\mathrm{pH}$ at about 6.5 to 6.7 in the downflow section and 7.5 in the upflow chamber where methane was produced.

Anaerobic Moving-Bed Biofilm Reactor. This reactor was developed to retain biomass for better COD reduction. The biofilm carrier particles provide a large surface area for biofilm to form. Formation of biofilm on the carrier particles provides stability by preventing cell losses in the effluent. Because the small carrier particles are not attached to the reactor, they can move as the waste is mixed. Wang et al. (2009) used a submersed pump to move the waste within the reactor. Good internal mixing avoids over-acidification associated with undiluted raw milk wastewater (Wang et al., 2009). In the AMBBR, a high volumetric load could be applied and a strong tolerance to shock loading was achieved (Wang et al., 2009).

Packed-Bed Immobilized Cell Bioreactor. This bioreactor is packed with large particles, such as 6.35 mm ceramic Intalox saddles, for cell immobilization. These particles do not move with the liquid, as with the AMBBR. External recirculation provides complete mixing. The system was successfully operated in a continuous mode to digest whey permeate with $\mathrm{pH}$ maintained at 7.0 (Yang and Guo, 1990). A high dilution rate can affect intermediate product formation, as it allows predominance of microbial groups having high adhesive properties. Yang and Guo (1990) reported that immobilized microorganisms can recover their activity within a week after months of starvation. The highest biogas production (3.3 L/L per day), and methane percentage $(69 \%)$ were obtained in the reactor packed with charcoal (Patel et al., 1999). This is because charcoal provides a better surface for attachment, biofilm formation, and adsorption sites for substrate (Patel et al., 1999). Blockage is a major problem associated with the packed-bed bioreactor.

Downflow Stationary Fixed-Film Reactor. This reactor is designed to prevent effluent plugging by high suspended solids concentration. Dairy food waste typically does not have high suspended solids concentration unless cheese fines are not removed from whey. Cánovas-Diaz and Howell (1987) used a 2-column downflow stationary fixed-film reactor for treating deproteinated cheese whey. When only one-third of the packaging support was submerged, the reactor performance was 90 to $95 \%$ at an organic loading rate of $12.5 \mathrm{~kg}$ of $\mathrm{COD} / \mathrm{m}^{3}$ per day with an HRT between 2 and 2.5 d. However, in the fully flooded mode, low organic loading rates are used to prevent accumulation of VFA and reactor failure.

Anaerobic Attached- (Fixed-) Film Expanded Bed. An anaerobic attached- (fixed-) film expanded bed consists of a column packed with inert sand-sized 
Table 3. Examples of mesophilic (unless otherwise noted) fermentation conditions and gas production from dairy processing waste

\begin{tabular}{|c|c|c|c|c|c|c|c|}
\hline Feed $^{1}(\mathrm{pH})$ & Reactor $^{2}$ & $\begin{array}{l}\mathrm{pH} \text { control } \\
\text { (1st, 2nd stage) }\end{array}$ & $\begin{array}{l}\mathrm{HRT}^{3} \\
\text { (d) }\end{array}$ & $\mathrm{OLR}^{4}$ & Biogas production & $\begin{array}{l}\mathrm{CH}_{4} \\
(\%)\end{array}$ & Reference \\
\hline $\mathrm{AW}$ & NMAD-NMAD & None & 15 & $488 \mathrm{~g} / \mathrm{d}$ & $0.05-0.10 \mathrm{~m}^{3}$ of $\mathrm{CH}_{4} / \mathrm{kg}$ of VS & $18-22$ & Ghaly (1989) \\
\hline AW & NMAD-NMAD & None, 5.7-6.0 & 20 & - & $0.224 \mathrm{~m}^{3} / \mathrm{kg}$ of COD added & 71 & Ghaly (1996) \\
\hline AW & NMAD-NMAD & None, 5.7 & 15 & $9.7 \mathrm{~L} / \mathrm{d}$ & $0.096 \mathrm{~L}$ of biogas/L per dav & 77 & Ghaly and Pyke (1991) \\
\hline $\mathrm{AW}(6.5)$ & CSTR-MCAB & None & 5 & - & $0.3 \mathrm{~L}$ of $\mathrm{CH}_{4} / \mathrm{g}$ of $\mathrm{COD}_{\text {removed }}$ & 70 & Saddoud et al. (2007) \\
\hline AW & UFFLR & 6.7 & 5 & $14.1 \mathrm{~kg}$ of $\mathrm{COD} / \mathrm{m}^{3}$ per day & $5.6 \mathrm{~m}^{3} / \mathrm{m}^{3}$ per day & 79 & Wildenauer and Winter (1985) \\
\hline CPW & CSTR-CSTR & $6.0,7.0$ & 5.7 & $60 \mathrm{~g}$ of soluble $\mathrm{COD} / \mathrm{L}$ & $\begin{array}{l}0.28 \mathrm{~L}^{2} \mathrm{CH}_{4} / \mathrm{g} \text { of soluble } \\
\mathrm{COD}\end{array}$ & 74 & Hwang (1997) \\
\hline $\mathrm{DPW}^{5}$ & DFR & 7.25 & 5 & $2.8 \mathrm{~kg}$ of $\mathrm{COD} / \mathrm{m}^{3}$ per day & $27 \mathrm{~m}^{3}$ of $\mathrm{CH}_{4} / \mathrm{kg}$ of $\mathrm{COD}$ & 50 & De Haast et al. (1986) \\
\hline FAW & ASBR & None & 3.2 & $1.6 \mathrm{~g}$ of $\mathrm{COD} / \mathrm{dm}^{3}$ per day & $\begin{array}{l}0.236 \mathrm{dm}^{3} \text { of } \mathrm{CH}_{4} / \mathrm{g} \text { of } \\
\mathrm{COD}_{\text {degraded }}\end{array}$ & 70 & Göblös et al. (2008) \\
\hline FW (7.2) & UAFR & None & 2 & $3 \mathrm{~g}$ of $\mathrm{COD} / \mathrm{L}$ per day & $280 \mathrm{~L} \mathrm{of} \mathrm{CH}_{4} / \mathrm{kg}$ of & - & Gannoun et al. (2008) \\
\hline PUFM $^{6}(7.0)$ & AMBBR & None & 3.2 & $17 \mathrm{~g}$ of $\mathrm{TCOD} / \mathrm{L}$ per day & $0.24 \mathrm{~L}$ of $\mathrm{CH}_{4} / \mathrm{g}$ of TCOD & - & Wang et al. (2009) \\
\hline $\mathrm{PUFW}^{7}$ & UASBR & 6.8 & 4 & $2.52 \mathrm{~kg}$ of $\mathrm{COD} / \mathrm{m}^{3}$ per day & $0.25 \mathrm{~L}$ of $\mathrm{CH}_{4} / \mathrm{g}$ of $\mathrm{COD}_{\text {removed }}$ & 73 & Hwang and Hansen (1992) \\
\hline SW. DWW (7.0) & UFFR & None & 2 & $15 \mathrm{~g}$ of $\mathrm{COD} / \mathrm{L}$ per day & $3.3 \mathrm{~L}$ of biogas / L dav & 69 & Patel et al. (1999) \\
\hline SW, DWW ${ }^{8}(7.0)$ & UFFR & None & 2 & - & $5.7 \mathrm{~L}$ of biogas/L per day & 77 & Patel and Madamwar (1998) \\
\hline SW, PW/CM & Batch & None & 9 & $2 \mathrm{~g}$ of TS/L per day & $0.4 \mathrm{~L} / \mathrm{L}$ per day & 64 & Patel and Madamwar (1996) \\
\hline $\mathrm{W}$ & CSTR-PABR & 5.2, none & 5.4 & - & 7.06 L of biogas/L per day & 71 & Antonopoulou et al. (2008) \\
\hline $\mathrm{W}^{9}$ & CSTR & 7.1 & 4.2 & - & $\begin{array}{l}4.65 \mathrm{mmol}^{\circ} \mathrm{CH}_{4} / \mathrm{mmol} \text { of } \\
\text { lactose }\end{array}$ & 51 & Chartrain and Zeikus (1986a) \\
\hline W & UFFR & 6.9 & 6.4 & - & $1,790 \mathrm{~L} / \mathrm{m}^{3}$ per day & 85.9 & Fox et al. (1992) \\
\hline $\mathrm{W}$ & CSTR-CSTR & 5, none & 1 & - & $0.182 \mathrm{~L}$ of $\mathrm{CH}_{4} / \mathrm{d}$ & 69 & Gough et al. (1987) \\
\hline $\mathrm{W}$ & CSTR-ARBCR & None & 6.1 & $8 \mathrm{~g}$ of VS/L per day & $3.75 \mathrm{~L}$ of $\mathrm{CH}_{4} / \mathrm{L}$ per day & 52 & Lo and Liao, 1988 \\
\hline $\mathrm{W}$ & DUHR & None & - & $10 \mathrm{~g}$ of $\mathrm{COD} / \mathrm{L}$ per day & $0.33 \mathrm{~nL}$ of $\mathrm{CH}_{4} / \mathrm{g}$ of $\mathrm{COD}$ & 53 & Malaspina et al. (1996) \\
\hline W & NMAD-NMAD & None, 7.0 & 15 & $3.16 \mathrm{~kg}$ of $\mathrm{VS} / \mathrm{m}^{3}$ per day & 0.18 biogas $/ L$ per day & 25 & Ramkumar et al. (1992) \\
\hline W & CSTR-CSTR & 5.2, none & 21 & - & $6.7 \mathrm{~L}$ of $\mathrm{CH}_{4} / \mathrm{L}$ of influent & 68 & Venetsaneas et al. (2009) \\
\hline W & CSTR-CSTR $^{10}$ & $6.0,7.0$ & 6 & $10 \mathrm{~g}$ of $\mathrm{COD} / \mathrm{L}$ & $0.60 \mathrm{~L}$ of $\mathrm{CH}_{4} / \mathrm{L}$ per day & 68.3 & Yang et al. (2003) \\
\hline $\mathrm{W}, \mathrm{CM}$ & ARBCR & None & 3 & $16.4 \mathrm{~g}$ of $\mathrm{VS} / \mathrm{L}$ per day & $3.74 \mathrm{~L}$ of $\mathrm{CH}_{4} / \mathrm{L}$ per day & 44 & Lo et al. (1988) \\
\hline $\mathrm{W}, \mathrm{CN}, \mathrm{PW}^{11}$ & ISTR & None & 10 & $6 \mathrm{~g}$ of TS/L per day & $4 \mathrm{~L}$ of $\mathrm{CH}_{4} / \mathrm{L}$ per day & 73 & Desai and Madamwar (1994a) \\
\hline $\mathrm{W}, \mathrm{CM}, \mathrm{PW}^{8}$ & ISTR & None & 10 & $6 \mathrm{~g}$ of TS/L per day & 3.0 L of biogas/L per day & 65 & Patel et al. (1996) \\
\hline
\end{tabular}

${ }^{1} \mathrm{AW}=$ acid whey; $\mathrm{CM}=$ cattle/dairy manure; $\mathrm{CPW}=$ cheese plant waste; $\mathrm{DPW}=$ deproteinized whey; DWW = dairy wastewater; $\mathrm{FAW}=$ prefermented acid whey; FW = prefermented whey; PUFM = permeate from UF of milk; PUFW = permeate from UF of whey; PW = poultry waste; $\mathrm{SW}=$ salt whey; $\mathrm{W}=$ whey. Feed $\mathrm{pH}$ is only noted if an ¿ adjustment was made.

${ }_{5}^{2} \mathrm{AMBBR}=$ anaerobic moving-bed biofilm reactor; ARBCR $=$ anaerobic rotating biological contact reactor; ASBR $=$ anaerobic sludge blanket reactor; $\mathrm{CSTR}=$ continuously stirred

D. tank reactor; DFR = downflow fixed-bed reactor; DUHR = downflow-upflow hybrid reactor; ISTR = intermittently stirred tank reactor; MCAB = membrane-coupled anaerobic

을 bioreactor; NMAD = no-mix anaerobic digester; PABR = periodic anaerobic baffled reactor; UAFR = upflow anaerobic filter; UASBR = upflow anaerobic sludge blanket reactor;

UFFR $=$ upflow fixed-film reactor; UFFLR $=$ upflow fixed-film loop reactor

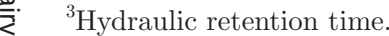

§) $\quad{ }^{4}$ Organic loading rate. $\mathrm{COD}=$ chemical oxygen demand; TCOD $=$ total COD; $\mathrm{VS}=$ volatile solids

Ф. ${ }^{5}$ Added urea.

${ }^{6}$ Added urea, mineral solution, and $\mathrm{NaHCO}_{3}$.

○ ${ }^{7}$ Added $\mathrm{KH}_{2} \mathrm{PO}_{4}$ and $\mathrm{NH}_{4} \mathrm{Cl}$.

$6{ }^{8}$ Added surfactant.

z ${ }^{9}$ Added phosphate buffer base

${ }^{10}$ Thermophilic temperature.

${ }^{11}$ Added silica gel. 
particles that expand with the upward flow of waste through the column. Particles increase the surface area and provide support for the growth of a biofilm (Switzenbaum and Danskin, 1982). This system allows good contact between the biomass and substrate while achieving high biomass concentration.

Upflow Fixed-Film Loop Reactor. In this system, porous clay beads were used to immobilize microorganisms. The $\mathrm{pH}$ was maintained at 6.7 and the content of the digester was recirculated 4 times per hour to facilitate separation of gas from the liquid (Wildenauer and Winter, 1985). When the circulation pump failed, gas replaced liquid in the fermentor, which reduced efficiency (Wildenauer and Winter, 1985).

Anaerobic Rotating Biological Contact Reactors. In the ARBCR, a series of discs and scrubbers are installed inside the reactor. The rotating discs act as a fixed-film supporting structure and their rotation provides mixing and enhances gas transfer to the head space. Scrubbers maintain the active volume of the reactor (Lo and Liao, 1986). In a 2-stage fermentation, Lo and Liao (1986) used a completely mixed reactor in the acidogenic phase and an ARBCR in the methanogenic phase. The physical separation of the 2 phases allowed more ethanol and VFA to be produced. The 2-stage design increased both methane content and production (Lo and Liao, 1986).

Membrane-Coupled Anaerobic Bioreactor. Most anaerobic digesters used nowadays are single pass with no selective solid recycle, which reduces the loading rate and biomass concentration (Saddoud et al. 2007). Independent control of HRT and solids retention times can be achieved by replacing a settlement system with a separation membrane (Kang et al. 2002; Saddoud et al. 2007). Saddoud et al. (2007) coupled microfiltration with a 2-stage bioreactor to remove soluble effluent and retain biomass. The microfiltration retentate was recycled into the methanogenic reactor. Although the membrane-coupled anaerobic bioreactor can solve the problem of biomass losses and produces a better quality effluent, biofouling is a major limitation of this technology. The optimum transmembrane pressure for flux reported by Saddoud et al. (2007) was $175 \mathrm{kPa}$. Kang et al. (2002) reported that backflushing improved the flux rate in both organic and inorganic membranes. Fouling of organic membranes was due to a surface cake layer of biomass and struvite $\left(\mathrm{MgNH}_{4} \mathrm{PO}_{4} \cdot 6 \mathrm{H}_{2} \mathrm{O}\right)$. However, struvite was found inside the pores of the inorganic membrane (Kang et al., 2002).

\section{Two-Stage Fermentation}

Anaerobic digestion of dairy food wastes such as whey and permeate is a challenge due to low bicar- bonate alkalinity, high COD, and rapid acidification. High concentrations of organic acids, the substrate of methanogenesis, can inhibit methanogens, which leads to process failure. Anaerobic digestion involves many species of symbiotic microorganisms that can be divided into 2 broad groups: acidogens and methanogens. These 2 groups differ considerably in their physiology, kinetics, and growth requirements (Yang et al., 2003). Operation of 2 separate digesters in series allows optimization of conditions for each of the 2 groups of microorganisms, decreases cost, and enhances process efficiency (Gough et al., 1987; Yang et al., 2003; Ke and Shi, 2005; Saddoud et al., 2007). The 2-stage anaerobic treatment is the most suitable for wastewater containing high levels of organic solids (Demirel et al., 2005). Despite the advantages of a 2 -stage process, complete acidification in a separate step can prevent formation of granular biomass in the anaerobic digester (Speece, 2008), which is important to the operation of many digester designs (e.g., UASBR). Partial acidification with small digesters in the first stage can be used to reduce cost (Yang et al., 2003). Rates of COD removal and methane production in a 2-stage reactor were 116 and $43 \%$ (respectively) higher than those in a single-stage unit (Yang et al., 2003). The optimal conditions in the acidification reactor were 0.4-d HRT, $10,000 \mathrm{mg}$ of $\mathrm{COD} / \mathrm{L}$, $\mathrm{pH}$ of 6.0 , and temperature of $54.1^{\circ} \mathrm{C}$, whereas the corresponding values in the methogenic reactor were $9.6 \mathrm{~d}$ HRT, $\mathrm{pH} 7.0$, and $55^{\circ} \mathrm{C}$ (Yang et al., 2003). According to the findings of Saddoud et al. (2007), optimum $\mathrm{pH}$ for the acidogenic and methanogenic stages were 6.5 and 7.3 to 8.5 , respectively. However, Gough et al. (1987) found that maintaining a $\mathrm{pH}$ value of 5.0 in the acidogenic reactor with a HRT of $24 \mathrm{~h}$ produced the highest levels of VFA and methane and lowest levels of $\mathrm{CO}_{2}$ and $\mathrm{COD}$.

A 2-stage process where a microfiltration membrane retained microorganisms, increased the volatile soluble solids from 6.4 to $10 \mathrm{~g} / \mathrm{L}$, and reached a $98.5 \%$ COD removal with gas production exceeding 10 times the volume of the reactor (Saddoud et al., 2007). Although no methane was produced in the first stage, $18 \%$ of the COD was removed. An organic loading rate higher than $8 \mathrm{~kg} \mathrm{COD} / \mathrm{m}^{3}$ per day requires $\mathrm{pH}$ control in the acidogenic reactor (García et al., 1991). Recirculation of the effluent from the methanogenic reactor diluted the influent and stabilized the $\mathrm{pH}$ with no need to add bases (García et al., 1991).

\section{pH Control}

Due to the limited buffering capacity of whey, the pH drops rapidly in anaerobic digesters (Ghaly, 1996). Ammonia formed during the decomposition of nitrog- 
enous compounds plays an important role as a buffer (Procházka et al., 2012). The buffering system in the anaerobic digester results from the interaction among 3 buffers: VFA [acetic acid with a dissociation constant (pKa) of 4.8], bicarbonate $\left(\mathrm{CO}_{2} / \mathrm{HCO}_{3}{ }^{-}\right.$with a pKa of 6.4), and ammonia formed from decomposition of nitrogenous compounds ( $\mathrm{pKa}$ of 9.25; Georgacakis et al., 1982; De Haast et al., 1986). A ratio of VFA (as acetic acid) to total alkalinity (as $\mathrm{CaCO}_{3}$ ) of less than 0.1 is desirable (Georgacakis et al., 1982). To maintain buffering and prevent inhibition of microorganisms, the $\mathrm{C}: \mathrm{N}$ ratio should be continuously monitored.

The optimum $\mathrm{pH}$ range for acidogenesis is about 5.5 to 6.5 (Kisaalita et al., 1987; Yu and Fang, 2002; Yang et al., 2003), whereas it ranges from 6.5 to 7.5 for methanogenesis (Ghaly and Ben-Hassan, 1989; Ghaly et al., 2000; Liu et al. 2008). With milk as a feed material, Yu and Fang (2002) reported that fat, protein, and carbohydrate degradation increased as $\mathrm{pH}$ was increased from 4.0 to 5.5; however, acetate and butyrate production were favored at $\mathrm{pH} 5.5$ to 6.0. Furthermore, acid and ethanol contents decreased as the $\mathrm{pH}$ was increased to 6.5 due to stimulation of methanogens and high rate of methane formation. The differences in $\mathrm{pH}$ between the acidogenic and methogenic phases support the case for 2-stage anaerobic fermentation of dairy waste. Low $\mathrm{pH}$ is expected to inhibit growth of methanogens and, consequently, reduce gas quantity and quality and COD removal (Ghaly and Pyke, 1991).

Anaerobic digestion of acid whey without $\mathrm{pH}$ control is infeasible due to the low rate and amount of gas production (Ghaly and Pyke, 1991). In a 2-stage anaerobic fermentation without $\mathrm{pH}$ control, the $\mathrm{pH}$ values were as low as 3.3 in both digesters (Ghaly and Pyke, 1991). Ghaly et al. (2000) found that after reactor failure, due to low $\mathrm{pH}$ (3.3), raising the $\mathrm{pH}$ to 7.0 did not restore methane production until the digester had been reseeded. A significant improvement in gas production and COD removal was observed when the $\mathrm{pH}$ in the outlet chamber was maintained between 5.7 and 6.0 (Ghaly and Pyke, 1991). The fermentation $\mathrm{pH}$ has a major effect on the production of intermediate products (Yu and Fang, 2002). Kisaalita et al. (1987) reported that no $\mathrm{CO}_{2}$ or hydrogen was produced from lactose if the startup $\mathrm{pH}$ was higher than 4.5. When the $\mathrm{pH}$ was less than 5 , butyrate was found to predominate, whereas acetate predominated at $\mathrm{pH}$ values higher than 5.5 (Kisaalita et al., 1987). Maintaining the $\mathrm{pH}$ of the whey permeate reactor at 6.0 resulted in lower amounts of the intermediate products butyrate and lactate (Yang and Guo, 1990). The conversion rate of propionate to acetate increased with increasing $\mathrm{pH}$, whereas the amount of propionate produced from lactose and lactate decreased with increasing pH (Yang and Guo, 1990).

The type of base used to control $\mathrm{pH}$ has an important effect on gas production. Methane content of biogas was $85.9 \%$ due to precipitation of $\mathrm{CaCO}_{3}$ when lime was mixed with the whey to maintain a $\mathrm{pH}$ value of 6.9 , before each subsequent feeding (Fox et al., 1992). Sodium and calcium in the base at concentrations above 8,000 $\mathrm{mg} / \mathrm{L}$ can have an inhibitory action (Grady and Lim, 1980). Also, ammonium nitrogen inhibits gas production at concentrations greater than 3,000 mg/L (Loehr, 1984). Calcium bases may increase gas production and methane levels by different mechanisms (Schröder and De Haast, 1989).

Calcium hydroxide precipitates $\mathrm{CO}_{2}$ in the form of $\mathrm{CaCO}_{3}$, which increases methane production rate and contents (Ghaly and Pyke, 1991). Also, calcium can help cells adhere to the substrate and stabilize the glucocalyx structure (Schröder and De Haast, 1989). Ionized Ca increases sludge flocculation (Lettinga et al., 1980). Venetsaneas et al. (2009) reported that addition of $\mathrm{NaHCO}_{3}$ to the raw whey (feed) at a concentration of $20 \mathrm{~g} / \mathrm{L}$ maintained the $\mathrm{pH}$ in the digester, but produced large amounts of $\mathrm{CO}_{2}$. Wang et al. (2009), however, reported that by adjusting the influent $\mathrm{pH}$ with $\mathrm{NaHCO}_{3}$, acidification was controlled by generating $\mathrm{CO}_{2}$. Replacing $68 \mathrm{mEq} / \mathrm{L}$ of $\mathrm{NaOH}$ with $80 \mathrm{mEq} / \mathrm{L}$ of $\mathrm{Na}_{2} \mathrm{CO}_{3}$ per liter resulted in a $15.5 \%$ increase in biogas and a $6.7 \%$ increase in methane from deproteinized whey in a downflow fixed-bed reactor (De Haast et al., 1986). Both bases $\left(\mathrm{NaOH}\right.$ and $\left.\mathrm{Na}_{2} \mathrm{CO}_{3}\right)$ could be replaced by $19 \mathrm{mEq} / \mathrm{L}$ of urea per liter of substrate (De Haast et al., 1986).

The need for $\mathrm{pH}$ control is one of the biggest limitations of anaerobic digestion of dairy food wastewater due to the additional cost (De Haast et al., 1985). A novel approach to prevent the reduction in $\mathrm{pH}$ with no external control is by fermentation of acid whey with the yeast Kluyveromyces lactis to produce ethanol before anaerobic digestion. Only acetic acid was detected in the bioreactor when the Kluyveromyces lactis-treated whey was used, whereas the biogas production rate was higher (1.92 times) at all OLR.

Addition of manure to dairy food waste can be beneficial to anaerobic digestion because it supplements nutrients and increases buffering capacity, which eliminates the need for $\mathrm{pH}$ control (Desai et al., 1994). The rate of gas production rate from cheese whey was much lower than that from dairy manure, even at the same solids concentration (Schröder and De Haast, 1989); however, similar biogas production was obtained from whey and dairy manure containing comparable TS and maintained at $\mathrm{pH} 5.7$ to 6.0 and 7.0, respectively (Ghaly, 
1996). Methane percentage from cheese whey without $\mathrm{pH}$ control was $20 \%$, whereas it was $60 \%$ from dairy manure, when all other factors were constant (Ghaly and Ben-Hassan, 1989). An ARBCR was successfully operated at an HRT of $2 \mathrm{~d}$ when whey was mixed with manure without pH control (Lo et al., 1988). However, the steady-state production could not be maintained at an HRT below $5 \mathrm{~d}$ when manure was not added (Lo et al., 1988; Ghaly and Pyke, 1991). Mixing poultry waste with whey dilutes it and prevents toxification from high ammonia levels (Desai et al., 1994). Although the combination of manure and whey or permeate is beneficial for digester control, the use of this treatment is limited. Either manure must be transported to the dairy plant digester site or dairy plant effluent must be transported to an animal agriculture digester site in a cost-effective manner. This is a limited solution for the dairy industry.

\section{Surfactants}

Surfactants improve performance of anaerobic digestion (Desai and Madamwar, 1994b; Patel et al., 1996; Petruy and Lettinga, 1997; Patel and Madamwar, 1998). Surfactants form micelles that enhance the coupling of sequential anaerobic reactions (Patel and Madamwar, 1998). They also emulsify milk fat, which increases the surface area available for lipolytic enzymes and bioavailability (Petruy and Lettinga, 1997). Surfactants vary in their effectiveness. For example, Tegopren 3022 at a concentration of $100 \mathrm{mg} / \mathrm{L}$ increased gas production by $45 \%$, methane content, the rate of VFA consumption, and COD removal (Patel et al., 1996). Sodium lauryl sulfate, which is an anionic surfactant, resulted in greater gas production, methane content, process stability, COD removal, and consumption of VFA than other surfactants such as Tegopren 3022, Tween 80, and Triton X-100 (Patel and Madamwar, 1998). The addition of the nonionic surfactant Tween 80 produced $3.5 \mathrm{~L}$ of gas/L of digester per day with $70 \%$ methane content (Desai and Madamwar, 1994b). Tween 80 reduces the stress in the digester by reducing propionic acid production (Desai and Madamwar, 1994b). However, high levels of surfactants can inhibit the methanogenic process. Sodium dodecylbenzensulfonate caused a 50 and $80 \%$ reduction in methanogenic activity at a concentration of 22 and $55 \mathrm{mg} / \mathrm{L}$, respectively (Desai and Madamwar, 1994b).

\section{Temperature}

Mesophilic fermentations are commonly used in the anaerobic digestion of dairy food wastewater for reasons stated previously. An increase in temperature from 20 to $40^{\circ} \mathrm{C}$ resulted in a gradual increase in gas production and proportion of methane from a mixture of cheese whey and animal waste (Desai et al., 1994). In such digesters, a second peak in gas production was obtained at $60^{\circ} \mathrm{C}$ (Lo et al., 1988; Desai et al., 1994). Fang and $\mathrm{Yu}(2001)$ observed an increase in lactose degradation in the acidogenic phase from 20 to $55^{\circ} \mathrm{C}$ with a decline at $60^{\circ} \mathrm{C}$. Wilson et al. (2008) found that acetate oxidation by methanogens at $57.5^{\circ} \mathrm{C}$ may limit the performance of anaerobic digesters. Two-stage fermentation allows temperature optimization for the acidogenic and methanogenic phases. Although Yang et al. (2003) reported that thermophilic anaerobic digestion can be a cost-effective process for treatment of waste with high organic strength because of the higher rate of methane production compared with the mesophilic process, Adams and Prairie (1988) reported no difference in performance between the mesophilic and thermophilic digestion of whey. The disagreement among research reports maybe due to differences in microbial populations. Because defined cultures are rarely used in anaerobic digestion research, no common conclusion can be drawn on the best fermentation temperature for anaerobic digestion of dairy wastes. For thermophilic fermentation to be feasible, a significant increase in methane production should be accomplished. Such data were not reported in the literature. Therefore, possibilities with thermophilic fermentation need to be further explored.

\section{C:N Ratio}

Very limited information is available on an optimum $\mathrm{C}: \mathrm{N}$ ratio for methane production, especially for dairy processing waste. Carbohydrate degradation rate is higher than that of protein, with lipid hydrolysis occurring at a much lower rate (Yu and Fang, 2002). Maintaining an optimum $\mathrm{C}: \mathrm{N}$ ratio is important to avoid accumulation of either nutrient, which leads to inefficient operation. Furthermore, the biodegradability of the carbon source should be considered because highly degradable carbon changes the acidogenesis-tomethanogenesis ratio and requires more neutralization (De Haast et al., 1985). Hills (1979) and Backus et al. (1988) demonstrated that methane production and percentage in biogas were affected by the C:N ratio. However, this was dependent on the HRT (Backus et al., 1988). Methane production was maximized from cheese whey at a C:N ratio of 22.2 and HRT of 18 and $30 \mathrm{~d}$ (Backus et al., 1988). At a 24-d HRT, the maximum methane production was achieved with a C:N ratio of 27.6 (Backus et al., 1988). At an HRT of $12 \mathrm{~d}$, the C:N ratio did not affect methane production 
(Backus et al., 1988). De Haast et al. (1985) reported an optimum C:N ratio of 20 for deproteinized whey, whereas a much higher ratio can lead to poor buffering and reactor failure. For comparison, Hills (1979) reported 25 as the optimum C:N ratio for methane production from cow manure. A C:N ratio of 7.5 with $308-\mathrm{mg} / \mathrm{L}$ ammonia concentration caused toxicity that reduced biomass yield and COD removal, and accumulated VFA (De Haast et al., 1985).

\section{HRT}

Generally, as the HRT increases, the substrate and COD value decrease, whereas the biogas production from cheese whey mixed with animal waste increases (Desai et al., 1994). At HRT longer than 12 d, the rate of methane production decreases (Desai et al., 1994). Volatile fatty acids, especially propionate, accumulate as the HRT decreases (Lo et al., 1988). This could be one explanation why gas production is reduced at short HRT (Ghaly, 1996). A significant increase in gas production, methane percentage, COD and VFA utilization, and process stabilization were obtained when HRT was increased from 1 to $2 \mathrm{~d}$, but not longer (Patel et al., 1999). Chartrain et al. (1987) reported that gas production was not affected by decreasing HRT from 100 to $25 \mathrm{~h}$. However, it dropped drastically with HRT shorter than $25 \mathrm{~h}$. The effect of HRT depends on different factors, such as temperature and $\mathrm{pH}$.

Maximum COD removal was obtained at $40^{\circ} \mathrm{C}$ and 9-d HRT or $60^{\circ} \mathrm{C}$ and 7-d HRT. A pH of 5.0 in the acidogenic reactor with an HRT of $24 \mathrm{~h}$ produced the maximum VFA and methane with the lowest $\mathrm{CO}_{2}$ and COD levels (Gough et al., 1987). The HRT affects not only biogas production, but also fermentation products. Zellner et al. (1987) found that acetate and propionate accumulated when the HRT was shorter than $6.25 \mathrm{~d}$, but butyrate accumulated when the HRT was decreased to $3.75 \mathrm{~d}$. At HRT shorter than $25 \mathrm{~h}$, acetate, formate, propionate, and butyrate increased and methane production decreased (Chartrain et al., 1987). Maximum methane ( $\mathrm{mmol} / \mathrm{mmol}$ of lactose) was obtained from 25- to 100-h HRT, but acetate, formate, and butyrate concentrations were highest at approximately $5 \mathrm{~h}$. However, lactate and ethanol continued to increase with HRT shorter than $5 \mathrm{~h}$.

Chartrain and Zeikus (1986a) reported that lactose was metabolized to lactate, ethanol, acetate, formate, and $\mathrm{CO}_{2}$ when the HRT was $100 \mathrm{~h}$. As the HRT decreased to less than $25 \mathrm{~h}$, acetate and propionate were the first to accumulate, followed by formate and butyrate, with lactate and ethanol being the lowest.

\section{Hydrogen Pressure}

Hydrogen pressure plays an important role in the control of the anaerobic fermentation process. Propionic and butyric acids are converted to acetic acid only under low hydrogen partial pressure (Ryhiner et al., 1993). The oxidation of propionic acid to acetic acid is thermodynamically possible if the hydrogen pressure is less than $10^{-4}$ atm (Thauer et al., 1977). The accumulation of propionic acid is accompanied by a drop in $\mathrm{pH}$, with an increase in dissolved hydrogen and acetic acid concentrations (Ryhiner et al., 1993; Yan et al., 1993). The high consumption rate of hydrogen in biofilms or floc by exopolysaccharides (Chartrain and Zeikus, 1986a) reduces the hydrogen concentration and allows conversion of butyric and propionic acids to acetic acid (Ryhiner et al., 1993). The utilization of hydrogen by lithotropic methanogens shifted sugar metabolism toward acetate (Mosey and Fernandes, 1989). Hydrogen pressure was reduced and hydrogen-utilizing methanogens were stimulated when the fermentation system was supplemented with trace elements (ferrous iron, copper, cobalt, nickel, zinc, and manganese); however, high concentrations of heavy metals can inhibit methanogenic organisms (Mosey and Fernandes, 1989). About 50\% methanogenesis inhibition was observed in the presence of copper chloride $(\geq 10 \mathrm{mg} / \mathrm{L})$, zinc chloride $(\geq 40 \mathrm{mg} / \mathrm{L})$, and nickel chloride $(\geq 60 \mathrm{mg} / \mathrm{L}$; Zayed and Winter, 2000). Methanogens are more sensitive to heavy metals than acidogens (Hickey et al., 1989). The simultaneous addition of sulfide with the heavy metals prevented their toxicity due to their precipitation as metal sulfides; however, the maximum concentration of sodium sulfide was $180 \mathrm{mg} / \mathrm{L}$ (Zayed and Winter, 2000).

\section{Other Factors}

The presence of high concentrations of sodium is detrimental to anaerobic fermentations (Backus et al., 1988). Diluting salt whey with total dairy wastewater at a $1: 2$ ratio and maintaining the influent $\mathrm{pH}$ at 7.0 could solve the problem (Patel et al., 1999). Selection of salt-tolerant microorganisms can improve fermentation of high-salt influent (Patel and Madamwar, 1998).

Bacterial populations that use lactose, lactate, and acetate increase concomitantly with lactose concentration (Chartrain et al., 1987). Increasing TS of a mixture of cattle dung, poultry waste, and cheese from 1 to $6 \%$ resulted in a gradual increase in gas production (Desai et al., 1994). Occasional ( $4 \mathrm{~h}$ per day at $120 \mathrm{rpm}$ ), but not continuous agitation improved the total gas production and reduced VFA concentration and COD (Desai 
et al., 1994). The application of adsorbents (silica gel, activated carbon, bentonite, aluminum powder, gelatin, and pectin) to $6 \%$ solids mixture of cheese whey and animal waste provided an environment more favorable for microbial growth. Adsorbents improved process efficiency, increased methane production and content, maintained a low hydrogen concentration, and reduced COD (Desai et al., 1994).

\section{DEFINED CULTURES}

The microorganisms involved in anaerobic digestion are not fully identified. Anaerobic digesters are always seeded with sewage sludge. Thus, the microflora within an anaerobic digester is very complex. Generally, acetogenic bacteria and methanogenic Archaea are the 2 groups of microorganisms involved in anaerobic fermentations. Limited information is available on the development of defined cultures to be used in anaerobic digestion of dairy food wastewater. Three groups of microorganisms representing hydrolytic, homoacetogenic, and methanogenic microorganisms were defined by Schug et al. (1987). Lactobacillus casei ssp. casei, Lactobacillus plantarum ssp. plantarum, and E. coli represented the hydrolytic bacteria, whereas Acetobacterium woodii, which converts lactate to acetate, represented the homoacetogenic bacteria (Schug et al., 1987). The 2 Archaea used by Schug et al. (1987) were Methanosarcina barkeri (converts acetate to methane and $\mathrm{CO}_{2}$ ) and Methanobacterium bryantii (forms methane from hydrogen and $\mathrm{CO}_{2}$ ). The inability of Methanobacterium bryantii to use hydrogen produced by $E$. coli enhanced methane production, whereas more methane was produced when the 2 methanogens were cocultured with $E$. coli (Schug et al. 1987). Hydrogen produced by E. coli inhibited acetate utilization by Methanosarcina barkeri, resulting in poor methane production. The combination of $L b$. plantarum, A. woodii, and M. barkeri was recommended for a high substrate conversion rate. In another study (Chartrain et al., 1987), Leuconostoc mesenteroides (hydrolytic), Desulfovibrio vulgaris (acetogenic), and $M$. barkeri and Methanobacterium formicicum (methanogenic) were selected based on the maximum growth rate $\left(\mu_{\max }\right)$ and substrate affinity constant $\left(\mathrm{K}_{\mathrm{s}}\right)$. An exopolysaccharide-producing Leuconostoc strain was selected to contribute to floc formation, which is desirable in anaerobic digesters (Chartrain and Zeikus, 1986b). The performance of the defined culture was similar to that in the adapted undefined culture in a continuous digestion of cheese whey and was effective in methane production at a 100-h HRT. A mixed-strain defined culture was also developed for anaerobic fermentation of whey permeate (Yang et al., 1988). The culture consisted of homolactic (Lactococcus lactis), homoacetic (Clostridium formicoaceticum), and acetate-utilizing methanogenic (Methanococcus mazei) strains. Supplementation of whey permeate with yeast extract and Trypticase was required for growth of the defined culture developed by Yang et al. (1988), and methane production was $5.3 \mathrm{~mol} / \mathrm{mol}$ of lactose. Also, the lack of propionic and butyric acids enhanced the methanogenic rate.

\section{CONCLUSIONS}

The body of work representing anaerobic treatment of dairy waste is substantial. Several areas of microbiology, biochemistry, and engineering relating to anaerobic digestion have been researched from many vantage points. Yet, the disposal issues associated with dairy food wastes remain and the use of anaerobic digestion seems ever more appropriate.

Increasing the methane proportion in biogas is important for generating energy and reducing the amount of $\mathrm{CO}_{2}$ released. Digester designs using 2 stages with separation between the acidogenic and methogenic reactions that retain high cell loading seem to be the most successful. The reactor $\mathrm{pH}$ should be maintained at 5 to 6 and 6 to 7 in the acidogenic and methogenic stages, respectively. Benefits of defined cultures are not known, but the potential is substantial. There is no doubt that much could be learned if research were conducted to identify organisms that have optimal COD reduction and methane generation. At the very least, microflora should be compared across many successful systems. For practical reasons, mesophilic conditions are recommended. In addition to treatment of dairy plant effluent, the challenge to researchers is to incorporate higher-strength waste from dairy manufacturing.

Landfills are common disposal areas for large amounts of out-of-specification product. Anaerobic fermentation would provide an option for use of this material. The best option may be delivering consistent waste products for anaerobic digestion instead of making the fermentation adapt to widely varying inputs. Combining dairy food wastes with manure has advantages, but the proximity of dairy food processing plants and animal agriculture prevents this option from becoming a common practice.

For decades, the dairy industry has used significant resources to optimize fermentations to produce dairy products for human consumption. These fermentations have been conducted on large, but appropriate, scale for financial success. It is likely that the microbiological work will mature for anaerobic digestion in a similar manner as starter culture research did for fermented dairy foods. Because off-odors associated with expansive ponds for aerobic waste treatment are not obvi- 
ous outside the enclosed vessels of anaerobic digesters, future work with anaerobic fermentation of waste must address the issues of scale and design so that this technology can be used near the dairy facilities, regardless of proximity to urban or residential areas.

\section{REFERENCES}

Adams, G. P., and D. M. Prairie. 1988. Monitoring and optimization program for completely mixed full-scale anaerobic digestion at a Canadian cheese plant. Pages 433-436 in Poster Papers 5th Int. Symp. Anaerobic Digestion. A. Tilche and A. Rozzi, ed. Monduzzi Editore, Bologna, Italy.

Aguilar, A., C. Casas, and J. M. Lema. 1995. Degradation of volatile fatty acids by differently enriched methanogenic cultures: Kinetics and inhibition. Water Res. 29:505-509.

Anderson, G. K., T. Donnelly, and K. J. McKeown. 1982. Identification and control of inhibition in the anaerobic treatment of industrial wastewater. Process Biochem. 17:28-32.

Antonopoulou, G., K. Stamatelatou, N. Venetsaneas, M. Kornaros, and G. Lyberatos. 2008. Biohydrogen and methane production from cheese whey in a two-stage anaerobic process. Ind. Eng. Chem. Res. 47:5227-5233.

Backus, B. D., C. J. Clanton, P. R. Goodrich, and H. A. Morris. 1988. Carbon-nitrogen ratio and hydraulic retention time effect on anaerobic digestion of cheese whey. Trans. ASAE 31:1274-1282.

Ben-Hassan, R. M., and A. E. Ghaly. 1994. Continuous propagation of Kluyveromyces fragilis in cheese whey for pollution potential reduction. Appl. Biochem. Biotechnol. 47:89-105.

Boone, D. R., and R. W. Castenholz. 2001. Bergey's Manual of Systematic Bacteriology. 2nd ed. Volume 1. Springer-Verlag, New York, NY.

Bullock, D. K., C. L. Hansen, and S. E. Poe. 1995. Carbon monoxide production from land applied cheese whey. Bioresour. Technol. 54:231-233.

Cammarota, M. C., G. A. Teixeira, and D. M. G. Freire. 2001. Enzymatic pre-hydrolysis and anaerobic degradation of wastewaters with high fat contents. Biotechnol. Lett. 23:1591-1595.

Cánovas-Diaz, M., and J. A. Howell. 1987. Downflow anaerobic filter stability studies. Process Biochem. 22:181-184.

Cavaleiro, A. J., M. A. Pereira, and M. Alves. 2008. Enhancement of methane production from long chain fatty acid based effluents. Bioresour. Technol. 99:4086-4095.

Chartrain, M., L. Bhatnagar, and J. G. Zeikus. 1987. Microbial ecophysiology of whey biomethanation: Comparison of carbon transformation parameters, species composition, and starter culture performance in continuous culture. Appl. Environ. Microbiol. 53:1147-1156.

Chartrain, M., and J. G. Zeikus. 1986a. Microbial ecophysiology of whey biomethanation: Intermediary metabolism of lactose degradation in continuous culture. Appl. Environ. Microbiol. 51:180187.

Chartrain, M., and J. G. Zeikus. 1986b. Microbial ecophysiology of whey biomethanation: Characterization of bacterial trophic populations and prevalent species in continuous culture. Appl. Environ. Microbiol. 51:188-196.

Cirne, D. G., L. Björnsson, M. Alves, and B. Mattiasson. 2006. Effects of bioaugmentation by an anaerobic lipolytic bacterium on anaerobic digestion of lipid-rich waste. J. Chem. Technol. Biotechnol. 81:1745-1752.

Cirne, D. G., X. Paloumet, L. Björnsson, M. M. Alves, and B. Mattiasson. 2007. Anaerobic digestion of lipid-rich waste - Effects of lipid concentration. Renew. Energy 32:965-975.

Clark, J. N. 1988. Utilization of acid and sweet wheys in a pilot-scale upflow anaerobic sludge blanket digester. N.Z. J. Dairy Sci. Tech. 23:305-327.

De Haast, J., T. J. Britz, and J. C. Novello. 1986. Effect of different neutralizing treatments on the efficiency of an anaerobic digester fed with deproteinated cheese whey. J. Dairy Res. 53:467-476.
De Haast, J., T. J. Britz, J. C. Novello, and E. W. Verwey. 1985 Anaerobic digestion of deproteinated cheese whey. J. Dairy Res. 52:457-467.

Demirel, B., O. Yenigun, and T. T. Onay. 2005. Anaerobic treatment of dairy wastewaters: A review. Process Biochem. 40:2583-2595.

Desai, M., and D. Madamwar. 1994a. Anaerobic digestion of a mixture of cheese whey, poultry waste and cattle dung: A study of the use of adsorbents to improve digester performance. Environ. Pollut. $86: 337-340$.

Desai, M., and D. Madamwar. 1994b. Surfactants in anaerobic digestion of cheese whey, poultry waste, and cattle dung for improved biomethanation. Trans. ASAE 37:959-962.

Desai, M., V. Patel, and D. Madamwar. 1994. Effect of temperature and retention time on biomethanation of cheese whey-poultry waste-cattle dung. Environ. Pollut. 83:311-315.

Fang, H. H. P., and H. Q. Yu. 2001. Acidification of lactose in wastewater. J. Environ. Eng. 127:825-831.

Fox, E. J., C. J. Clanton, P. R. Goodrich, B. D. Backus, and H. A. Morris. 1992. Liming an anaerobic cheese whey digester. Trans. ASAE 35:269-274.

Gannoun, H., E. Khelifi, H. Bouallagui, Y. Touhami, and M. Hamdi. 2008. Ecological clarification of cheese whey prior to anaerobic digestion in upflow anaerobic filter. Bioresour. Technol. 99:61056111.

García, P. A., J. L. Rico, and F. Fdz-Polanco. 1991. Anaerobic treatment of cheese whey in a two-phase UASB reactor. Environ. Technol. 12:355-362.

Georgacakis, D., D. M. Sievers, and E. L. Iannotti. 1982. Buffer stability in manure digesters. Agric. Wastes 4:427-441.

Ghaly, A. E. 1989. Biogas production from acid cheese whey using a two-stage digester. Energy Sources 11:237-250.

Ghaly, A. E. 1996. A comparative study of anaerobic digestion of acid cheese whey and dairy manure in a two-stage reactor. Bioresour. Technol. 58:61-72.

Ghaly, A. E., and R. M. Ben-Hassan. 1989. Continuous production of biogas from dairy manure using an innovative no-mix reactor. Appl. Biochem. Biotechnol. 20-21:541-559.

Ghaly, A. E., and J. B. Pyke. 1991. Amelioration of methane yield in cheese whey fermentation by controlling the $\mathrm{pH}$ of the methanogenic stage. Appl. Biochem. Biotechnol. 27:217-237.

Ghaly, A. E., D. R. Ramkumar, S. S. Sadaka, and J. D. Rochon. 2000. Effect of reseeding and $\mathrm{pH}$ control on the performance of a twostage mesophilic anaerobic digester operating on acid cheese whey. Can. Agric. Eng. 42:173-183

Göblös, Sz., P. Portörő, D. Bordás, M. Kálmán, and I. Kiss. 2008. Comparison of the effectivities of two-phase and single-phase anaerobic sequencing batch reactors during dairy wastewater treatment. Renew. Energy 33:960-965.

Gough, R. H., D. Roy, and T. R. McDowell. 1987. Methane generation from digestion of whey in a two-stage system. J. Environ. Sci. Health 5:463-483.

Grady, C. P. L., and H. C. Lim. 1980. Biological Wastewater Treatment. Marcel Dekker Inc., New York, NY.

Hanaki, K., T. Matsuo, and M. Nagase. 1981. Mechanisms of inhibition caused by long chain fatty acids in anaerobic digestion process. Biotechnol. Bioeng. 23:1591-1610.

Hickey, R. F., J. Vanderwielen, and M. S. Switzenbaum. 1989. The effect of heavy metals on methane production and hydrogen and carbon monoxide levels during batch anaerobic sludge digestion. Water Res. 23:207-219.

Hills, D. J. 1979. Effects of carbon:nitrogen ratio on anaerobic digestion of dairy manure. Agric. Wastes 1:267-278.

Hobman, P. G. 1984. Review of processes and products for utilization of lactose in deproteinated milk serum. J. Dairy Sci. 67:26302653.

Hwang, S. 1997. Feasibility assay in phase-separated anaerobic treatment of cheese industry wastewater. Biotechnol. Bioprocess Eng. $2: 53-58$.

Hwang, S. H., and C. L. Hansen. 1992. Performance of upflow anaerobic sludge blanket (UASB) reactor treating whey permeate. Trans. ASAE 35:1665-1671. 
Kang, I.-J., S.-H. Yoon, and C.-H. Lee. 2002. Comparison of the filtration characteristics of organic and inorganic membranes in a membrane-coupled anaerobic bioreactor. Water Res. 36:1803-1813.

Ke, S., and Z. Shi. 2005. Applications of two-phase anaerobic degradation in industrial wastewater treatment. Int. J. Environ. Pollut. 23:65-80.

Kemp, D. L., and J. Quickenden. 1988. Whey processing for profit-A worthy alternative. Pages 323-331 in Resources and Applications of Biotechnology - The New Wave. R. Greenshields, ed. Macmillan Press, Basingstoke, UK.

Kim, S.-H., S.-K. Han, and H.-S. Shin. 2004. Two-phase anaerobic treatment system for fat-containing wastewater. J. Chem. Technol. Biotechnol. 79:63-71.

Kisaalita, W. S., K. V. Lo, and K. L. Pinder. 1990. Influence of whey protein on continuous acidogenic degradation of lactose. Biotechnol. Bioeng. 36:642-646.

Kisaalita, W. S., K. L. Pinder, and K. V. Lo. 1987. Acidogenic fermentation of lactose. Biotechnol. Bioeng. 30:88-95.

Koster, I. W., and G. Lettinga. 1988. Anaerobic digestion at extreme ammonia concentrations. Biological Wastes 25:51-59.

Lalman, J. A., and D. M. Bagley. 2000. Anaerobic degradation and inhibitory effects of linoleic acid. Water Res. 34:4220-4228

Lalman, J. A., I. Komjarova, and N. Jing. 2004. Lactose fermentation in the presence of $\mathrm{C} 18$ fatty acids. J. Chem. Technol. Biotechnol. 79:1259-1267.

Lee, C., J. Kim, S. G. Shin, and S. Hwang. 2008. Monitoring bacterial and archaeal community shifts in a mesophilic anaerobic batch reactor treating a high-strength organic wastewater. FEMS Microbiol. Ecol. 65:544-554.

Lettinga, G., A. F. M. van Velsen, S. W. Hobma, W. de Zeeuw, and A. Klapwijk. 1980. Use of the upflow sludge blanket (USB) reactor concept for biological wastewater treatment, especially for anaerobic treatment. Biotechnol. Bioeng. 22:699-734.

Liu, C.-F., X.-Z. Yuan, G.-M. Zeng, W.-W. Li, and J. Li. 2008. Prediction of methane yield at optimum $\mathrm{pH}$ for anaerobic digestion of organic fraction of municipal solid waste. Bioresour. Technol. 99:882-888.

Lo, K. V., and P. H. Liao. 1986. Digestion of cheese whey with anaerobic rotating biological contact reactors. Biomass 10:243-252.

Lo, K. V., and P. H. Liao. 1988. Laboratory scale studies on the mesophilic anaerobic digestion of cheese whey in different digester configurations. J. Agric. Eng. Res. 39:99-105.

Lo, K. V., P. H. Liao, and C. Chiu. 1988. Mesophilic anaerobic digestion of a mixture of cheese whey and dairy manure. Biomass $15: 45-53$

Loehr, R. C. 1984. Pollution Control for Agriculture. 2nd ed. Academic Press, New York, NY.

Malaspina, F., C. M. Cellamare, L. Stante, and A. Tilche. 1996. Anaerobic treatment of cheese whey with a downflow-upflow hybrid reactor. Bioresour. Technol. 55:131-139.

Mawson, A. J. 1994. Bioconversions for whey utilization and waste abatement. Bioresour. Technol. 47:195-203.

McCarty, P. L. 1964. Anaerobic waste treatment fundamentals: Part one: Chemistry and microbiology. Public Works 95:107-112.

McCarty, P. L., and D. P. Smith. 1986. Anaerobic waste water treatment. Environ. Sci. Technol. 20:1200-1206.

McInerney, M. J. 1988. Anaerobic hydrolysis and fermentation of and proteins. Pages 373-415 in Biology of Anaerobic Microorganisms. A. J. B. Zehnder, ed. John Wiley and Sons, New York, NY.

Miyamoto, K. 1997. Renewable biological systems for alternative sustainable energy production. FAO Agricultural Services Bulletin No. 128. Food and Agriculture Organization of the United Nations (FAO), Rome, Italy.

Mosey, F. E., and X. A. Fernandes. 1989. Patterns of hydrogen in biogas from the anaerobic digestion of milk-sugars. Water Sci. Technol. 21:187-196.

Nagase, M., and T. Matsuo. 1982. Interactions between amino acid degrading bacteria and methanogenic bacteria in anaerobic digestion. Biotechnol. Bioeng. 24:2227-2239.
Parkin, G. F., R. E. Speece, C. H. J. Yang, and W. M. Kocher. 1983. Response of methane fermentation system to industrial toxicants. J. Water Pollut. Control Fed. 55:44-53.

Patel, C. and D. Madamwar. 1996. Biomethanation of a mixture of salty cheese whey and poultry water or cattle dung. A study of effect of temperature and retention time. Appl. Biochem. Biotechnol. 60:159-166.

Patel, C., V. Sastry, and D. Madamwar. 1996. Tegoprens in anaerobic digestion of a mixture of a cheese whey, poultry waste, and cattle dung for improved biomethanation. Appl. Biochem. Biotechnol. 56:89-94.

Patel, P., and D. Madamwar. 1998. Surfactants in anaerobic digestion of salty cheese whey using upflow fixed film reactor for improved biomethanation. Process Biochem. 33:199-203.

Patel, P., C. Patel, and D. Madamwar. 1999. Anaerobic upflow fixedfilm bioreactor for biomethanation of salty cheese whey. Appl. Biochem. Biotechnol. 76:193-201.

Pereira, M. A., O. C. Pires, M. Mota, and M. M. Alves. 2005. Anaerobic biodegradation of oleic and palmitic acids: Evidence of mass transfer limitations caused by long chain fatty acid accumulation onto the anaerobic sludge. Biotechnol. Bioeng. 92:15-23.

Pereira, M. A.. D. Z. Sousa, M. Mota, and M. M. Alves. 2004. Mineralization of LCFA associated to anaerobic sludge: Kinetics, transport limitations, enhancement of methanogenic activity and effect of VFA. Biotechnol. Bioeng. 88:502-511.

Perle, M., S. Kimchie, and G. Shelef. 1995. Some biochemical aspects of the anaerobic degradation of dairy wastewater. Water Res. 29:1549-1554

Petruy, R., and G. Lettinga. 1997. Digestion of a milk-fat emulsion Bioresour. Technol. 61:141-149.

Procházka, J., P. Dolejš, J. Máca, and M. Dohányos. 2012. Stability and inhibition of anaerobic processes caused by insufficiency or excess of ammonia nitrogen. Appl. Microbiol. Biotechnol. 93:439 447.

Ramkumar, D. R., A. E. Ghaly, and J. B. Pyke. 1992. Anaerobic digestion of cheese whey with $\mathrm{pH}$ control. American Society of Agricultural Engineers (ASAE) meeting presentation. Paper no. 92-6606:1-34. ASAE, St. Joseph, MI.

Ramsay, I. R., and P. C. Pullammanappallil. 2001. Protein degradation during anaerobic wastewater treatment: Derivation of stoichiometry. Biodegradation 12:247-257.

Ryhiner, G. B., E. Heinzle, and I. J. Dunn. 1993. Modeling and simulation of anaerobic wastewater treatment and its application to control design: Case whey. Biotechnol. Prog. 9:332-343.

Rosa, D. R., I. C. S. Duarte, N. K. Saavedra, M. B. Varesche, M. Zaiat, M. C. Cammarota, and D. M. G. Freire. 2009. Performance and molecular evaluation of an aerobic system with suspended biomass for treating wastewater with high fat content after enzymatic hydrolysis. Bioresour. Technol. 100:6170-6176.

Saddoud, A., I. Hassaïri, and S. Sayadi. 2007. Anaerobic membrane reactor with phase separation for the treatment of cheese whey. Bioresour. Technol. 98:2102-2108.

Sage, M., G. Daufin, and G. Gesan-Guiziou. 2008. Effects of prehydrolysis of milk fat on its conversion to biogas. J. Dairy Sci. 91:4062-4074.

Schröder, E. W., and J. De Haast. 1989. Anaerobic digestion of deproteinated cheese whey in an upflow sludge blanket reactor. J. Dairy Res. 56:129-139.

Schug, A., S. M. Schoberth, and H. Sahm. 1987. Conversion of lactose to methane by defined bacterial cocultures. Acta Biotechnol. $7: 337-345$.

Skiadas, I. V., and G. Lyberatos. 1998. The periodic anaerobic baffled reactor. Water Sci. Technol. 38:401-408.

Speece, R. E. 2008. Anaerobic Biotechnology and Odor/Corrosion Control for Municipalities and Industries. Archae Press, Nashville, TN.

Stams, A. J. M., C. Dijkema, C. M. Plugge, and P. Lens. 1998. Contribution of ${ }^{13} \mathrm{C}-\mathrm{NMR}$ spectroscopy to the elucidation of methanogenic environments. Biodegradation 9:463-473. 
Switzenbaum, M. S., and S. C. Danskin. 1982. Anaerobic expanded bed treatment of whey. Agric. Waste 4:411-426.

ten Brummeler, E., L. W. Hulshoff Pol, J. Dolfing, G. Lettinga, and A. J. B. Zehnder. 1985. Methanogenesis in an upflow anaerobic sludge blanket reactor at $\mathrm{pH} 6$ on an acetate-propionate mixture. Appl. Environ. Microbiol. 49:1472-1477.

Thauer, R. K., K. Jungermann, and K. Decker. 1977. Energy conservation in chemotrophic anaerobic bacteria. Bacteriol. Rev. 41:100-180.

Tzeng, C. H. 1985. Applications of starter cultures in the dairy industry. Develop. Industr. Microbiol. 16:323-338.

Venetsaneas, N., G. Antonopoulou, K. Stamatelatou, M. Kornaros, and G. Lyberatos. 2009. Using cheese whey for hydrogen and methane generation in a two-stage continuous process with alternative $\mathrm{pH}$ controlling approaches. Bioresour. Technol. 100:3713-3717.

Vidal, G., A. Carvalho, R. Méndez, and J. M. Lema. 2000. Influence of the content in fats and proteins on the anaerobic biodegradability of dairy wastewaters. Bioresour. Technol. 74:231-239.

Wang, S., N. Chandrasekhara Rao, R. Qiu, and R. Moletta. 2009. Performance and kinetic evaluation of anaerobic moving bed biofilm reactor for treating milk permeate from dairy industry. Bioresour. Technol. 100:5641-5647.

Wildenauer, F. X., and J. Winter. 1985. Anaerobic digestion of highstrength acidic whey in a $\mathrm{pH}$-controlled up-flow fixed film loop reactor. Appl. Microbiol. Biotechnol. 22:367-372.

Wilson, C. A., S. M. Murthy, Y. Fang, and J. Novak. 2008. The effect of temperature on the performance and stability of thermophilic digestion. Water Sci. Technol. 57:297-304.

Yan, J. Q., K. V. Lo, and K. L. Pinder. 1993. Instability caused by high strength of cheese whey in a UASB reactor. Biotechnol. Bioeng. 41:700-706.
Yang, K., Y. Yu, and S. Hwang. 2003. Selective optimization in thermophilic acidogenesis of cheese whey wastewater to acetic and butyric acids: Partial acidification and methanation. Water Res. 37:2467-2477.

Yang, S. T., and M. Guo. 1990. Kinetics of methanogenesis from whey permeate in packed bed immobilized cells bioreactor. Biotechnol. Bioeng. 36:427-436.

Yang, S. T., I.-C. Tang, and M. R. Okos. 1988. Defined bacterial culture development for methane generation from lactose. Biotechnol. Bioeng. 32:28-37.

Yu, H. Q., and H. H. P. Fang. 2001. Acidification of mid- and highstrength dairy wastewaters. Water Res. 35:3697-3705.

Yu, H.-Q., and H. H. P. Fang. 2002. Acidogenesis of dairy wastewater at various $\mathrm{pH}$ levels. Water Sci. Technol. 45:201-206.

Zayed, G., and J. Winter. 2000. Inhibition of methane production from whey by heavy metals - Protective effect of sulfide. Appl. Microbiol. Biotechnol. 53:726-731.

Zellner, G., P. Vogel, H. Kneifel, and J. Winter. 1987. Anaerobic digestion of whey and whey permeate with suspended and immobilized complex and defined consortia. Appl. Microbiol. Biotechnol. $27: 306-314$

Zellner, G., and J. Winter. 1987. Analysis of a highly efficient methanogenic consortium producing biogas from whey. Syst. Appl. Microbiol. 9:284-292.

Zindel, U., W. Freudenberg, M. Rieth, J. R. Andreesen, J. Schnell, and F. Widdel. 1988. Eubacterium acidaminophilum sp. nov., a versatile amino acid-degrading anaerobe producing or utilizing $\mathrm{H}_{2}$ or formate. Arch. Microbiol. 150:254-266. 